\title{
Priorities of social and economic safety
}

\author{
Vasiliy Nechaev ${ }^{1, *}$, Pavel Mikhailushkin ${ }^{2}$, and Denis Presnyakov ${ }^{2}$ \\ ${ }^{1}$ Federal Research Center of Agrarian Economy and Social Development of Rural Areas - All \\ Russian Research Institute of Agricultural Economics, 123007, Khoroshevskoe shosse, 35k2, \\ Moscow, Russia \\ ${ }^{2}$ Kuban State Agrarian University named after I. T. Trubilin, 350004, Kalinina str., 13, Krasnodar, \\ Russia
}

\begin{abstract}
The purpose is to consider the main theoretical approaches to definition of social safety and estimate its conditions. The analysis of economic indicators of 2016-2017 has shown that with a growth of the key economic indicators, negative dynamics of the real located income of the population still remain. In the article, the importance of social and economic safety is emphasized. The two main conditions of economic safety provide the presence of the influential middle class and a ratio between the minimum and maximum income of the population. By means of Lorentz's curve, the increase of stratification of the population on income is shown. The article concludes that that poverty is a threat of economic security, because it slows down economic growth. The authors also assess the influence of administrative impact on social and economic development of regions, finding a weak reliance.
\end{abstract}

Among the existing aspects of economic security (demographic, economic, investment, social, environmental, information, etc.), the priority is to ensure the security of the socioeconomic system as a combination of the above-mentioned species that threaten the stability of Russian society, its citizens and the state as a whole. The social sphere is organically included in the economic system of the country. Its development, like the development of any other manufacturing industry, directly affects the security of the country and regions.

The emergence of a variety of threats and dangers in the development of the socioeconomic system necessitates a far-sighted policy regarding the quality of human capital, the development of a mechanism for ensuring security, clarifying and concretizing certain theoretical positions.

Economic security is the state of an economic entity, characterized by the availability of resources that allow it to maintain a standard of living for the present and for the foreseeable future. The term "social and economic security" takes into account the creation and development of human capital.

L. N. Dobryshina defines social and economic security as a special state of the economy and its various institutions, under which the economic system is able to respond

\footnotetext{
* Corresponding author: vin981@yandex.ru
} 
painlessly to the emerging internal and external threats, as well as special conditions for sustainable socio-economic development and reproduction [1].

With respect to the region, L. M. Eremeev believes that this is the "ability of the region to resist negative influences of various kinds (crises, social instability, etc.), rapidly returning to its original state, or to achieve a higher point of its development, a steady improvement in the quality of life population, and the provision of expanded reproduction of the territorial-economic complex" [2].

2016 is the year of stabilization of the Russian economy, the transition from recession to recovery growth. Along with the growth of GDP by $1.5 \%$ and the indicators in industry, agriculture, retail trade in 2017 (Table 1), we note a low level of inflation. Nevertheless, the achieved growth rates are lower than official forecasts, and the stabilization of the situation is largely due to the resumed rise in commodity prices, as well as the growth of public investment.

Table 1. Key indicators of the development of the economy of Russia, In \% to the previous year.

\begin{tabular}{|l|c|c|}
\hline Indicators of economic development & 2016 year & 2017 year \\
\hline GDP & 99,8 & 101,5 \\
Consumer price index & 105,4 & 102,5 \\
Index of industrial production & 101,1 & 101,0 \\
Agricultural production index & 103,4 & 102,4 \\
Work in construction" & 95,7 & 98,6 \\
Real disposable money income of the population & 94,1 & 98,3 \\
Retail trade turnover & 94,8 & 101,2 \\
The volume of paid services to the population & 99,7 & 100,2 \\
Oil price Urals & 81,7 & 126,6 \\
Incomes of the federal budget & 98,6 & 112,1 \\
Expenditures of the federal budget & 105,3 & 100,0 \\
\hline
\end{tabular}

Source: Ministry of Economic Development, Rosstat, Ministry of Finance

As Vladimir Putin noted, "In general, the Russian economy is now less ex-posed to all kinds of external shocks and impacts" [3].

Such a positive assessment is due to the steady fulfillment of the social obligations of the government of the Russian Federation, the successful control of the situation in the national economy with low oil prices and Western sanctions, the subsequent devaluation of the Russian rubles; the achievement of a record low inflation, which creates new conditions for the growth of the Russian economy.

However, further exacerbation of external factors affecting economic security is accompanied by a number of socio-economic problems, which causes the urgency of the research. As can be seen from the data in Table 1, with the growth of the main economic indicators, negative dynamics of real disposable incomes of the population still, unfortunately, remain.

Assessing the impact of global risks on the Russian economy, V. K. Senchagov and A. N. Solovyev identified groups of external and internal factors affecting economic security (Fig. 1).

\begin{tabular}{|c|c|}
\hline \multicolumn{2}{|c|}{ Factors affecting economic security } \\
\hline$\downarrow$ & $\downarrow$ \\
\hline External & Internal \\
\hline $\begin{array}{l}\text { - High income inequality in } \\
\text { industrialized and developing countries; } \\
\text { - High unemployment; } \\
\text { - Budget crises of leading economies of } \\
\text { the world; } \\
\text { - Violation of the functioning of the }\end{array}$ & $\begin{array}{l}\text { - Lower average annual GDP growth rates; } \\
\text { - Decrease in the level of investments in the main } \\
\text { capital; } \\
\text { - The ratio of the number of people in retirement } \\
\text { and working age; } \\
\text { - Share of the population with incomes below the }\end{array}$ \\
\hline
\end{tabular}




\begin{tabular}{|l|l|l|}
$\begin{array}{l}\text { main financial institutions and } \\
\text { mechanisms }\end{array}$ & $\begin{array}{l}\text { subsistence minimum; } \\
\text { - Reduction of the size of gold and foreign } \\
\text { exchange reserves; } \\
\text { - An increase in the level of inflation. }\end{array}$ \\
\hline
\end{tabular}

Fig. 1. The most significant factors affecting the level of economic security Source: [4]

The growing social and economic stratification of the population is becoming one of the acute problems of our time.

The main conditions for ensuring an acceptable level of socio-economic security and stability in society include the creation of a fairly influential middle class [5]; the ratio between the minimum and maximum incomes of the population.

According to the International company IPSOS [6], the middle class in Russia is 5\% of the population, which is characterized by an average income in the family of 79 thousand rubles per person (average income for Russia is 26.5 thousand rubles per person), the presence of a car (95\%), an apartment being in property $(83 \%, 62 \%$ live in an apartment of 3 or more rooms). The middle class in Russia is not sufficiently influential.

The differentiation of the monetary incomes of the population is estimated using the Lorentz curve. The constructed Lorentz curve for Russia in the dynamics (Fig. 2) shows that the population stratification by income is strengthened.

Note that the Lorenz curves for the years of 1970, 1980, and 1990 are approximately similar, the main growth of the population stratification by income began in the $90 \mathrm{~s}$, which is due to those economic reforms. The forecast curve is constructed from the data for 19702016 and shows further growth of the stratification in the future and strengthening of inequality.

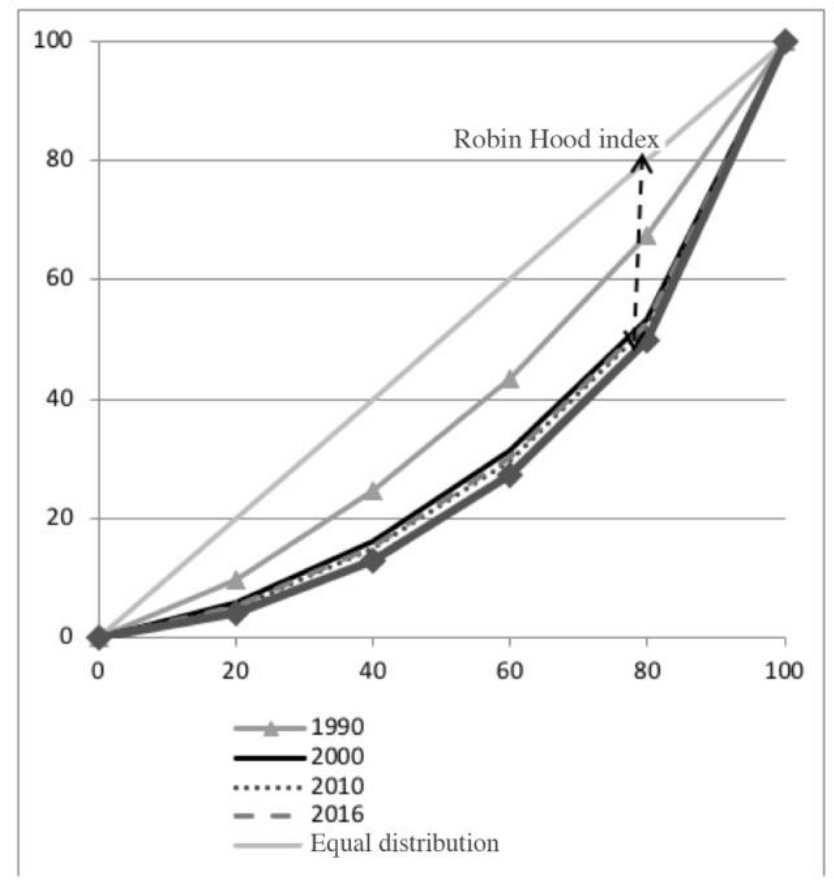

Fig. 2. The Lorentz curve for Russia for 1990-2016 and its forecast.

Figure 2 also shows the Robin Hood index, or the Hoover index, which is equal to the share of the income of society that needs to be redistributed to achieve equality. In 2016, it 
amounted to $29.7 \%$, in the forecast version, $32.8 \%$, i.e. redistribution of a third of the total income of society can achieve equality in income. The decline in oil prices and international sanctions led to the fact that the standard of living of Russia in 2017 did not significantly im-prove.

The cross-country comparison of income distribution (Figure 3) shows roughly the same ratio for the US, Russia and China, more equitable in Kazakhstan and Belarus, and the most unfair in the South African Republic.

According to the World Bank, at the end of the 20th century, 20\% of humanity had more than $4 / 5$ of world income. This is mainly the residents of industrialized countries. Statistics on the distribution of income do not show which part of the population provides their income at the expense of labor, and which one by at the expense of property. Revenues from property in the structure of income in Russia amounted to $6.5 \%$ in 2016, and it was $64.6 \%$ for wages. In Sweden, for example, $5 \%$ of households own $77 \%$ of the shares of their total number, i.e. the income from the property of the population group prevails, while the Gini coefficient is low.

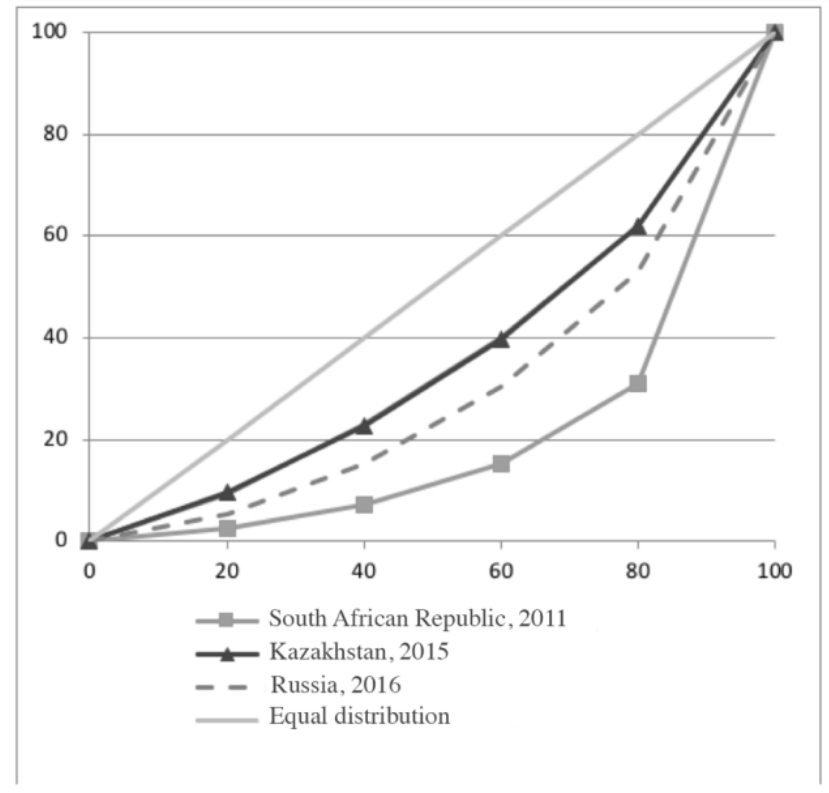

Fig. 3. Intercountry comparison of the degree of socio-economic stratification of the population. Source: [7]

According to official data of the Federal State Statistics Service in Russia in 2016, 20.3 million poor, i.e. $14 \%$ of those whose income level is below the subsistence level. This indicator does not take into account pensioners, because according to the government's decree, pensioners are paid surcharges to bring their pensions to the subsistence level. Pensioners who receive co-payments account for $16.7 \%$ or 5.3 million people. And with an average pension of 11.9 thousand rubles, all 43.8 million pensioners can be considered poor.

According to Rosstat, about 2 million Russians receive salaries below the subsistence minimum (7.3\% of those working in April 2017). The share of poor workers in the state sector is 4 times higher than in the private sector.

The majority of the poor in Russia are the working people with children. The ranking of regions on the welfare of Russian families (Table 2) shows that in some regions, occupying the last places in the rating year after year, the chronic poverty of families is formed, and it 
is difficult to get out of it. To significantly increase income, you need to raise the level of education, acquire a new profession, or even move. More than that, the labor market supply does not provide a higher salary and retain professional status, and employment does not lead to increased incomes.

Table 2. Rating of regions on the welfare of Russian families by the end of 2016 (fragment).

\begin{tabular}{|c|c|c|c|c|}
\hline \multicolumn{2}{|c|}{ Place in } & \multirow[t]{2}{*}{ Region } & \multicolumn{2}{|c|}{$\begin{array}{l}\text { The balance of the family's money after } \\
\text { the minimum expenditure, rubles in } \\
\text { months in } 2016\end{array}$} \\
\hline 2016 г. & 2015 г. & & Two children & One children \\
\hline$\ldots$ & $\cdots$ & & 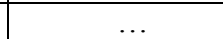 & \\
\hline 76 & 77 & Kabardino-Balkaria Republic & 7574 & 17276 \\
\hline 77 & 81 & Smolensk region & 7558 & 17738 \\
\hline 78 & 74 & Republic of North Ossetia-Alania & 7441 & 16452 \\
\hline 79 & 69 & Kurgan region & 6526 & 15577 \\
\hline 75 & 79 & Republic of Kalmykia & 7628 & 16132 \\
\hline 80 & 78 & Karachay-Cherkess Republic & 6359 & 15346 \\
\hline 81 & 82 & Ingushetia & 5468 & 14436 \\
\hline 82 & 83 & Altai region & 4558 & 14039 \\
\hline 83 & 84 & Ivanovo region & 2943 & 12064 \\
\hline 84 & 85 & Dagestan & 1097 & 11396 \\
\hline 85 & 80 & Pskov region & -1970 & 9536 \\
\hline
\end{tabular}

Ranked by the balance of cash for a family with two children

Source: [7]

The vicious circle of poverty can be "broken" by increasing the growth rate of capital accumulation and raising the level of investment up to $10 \%$ of GDP, while controlling population growth [8]. This will lead to an increase in per capita income, an increase in savings, an increase in labor productivity, and personal income.

Since January 1, 2018, the minimum wage has been raised to $85 \%$ of the subsistence minimum. It will be up to $100 \%$ since January 1,2019 . This will reduce poverty and inequality to some extent. However, it will not solve the problem of poverty, since the minimum wage is calculated on the basis of the cost of the consumer basket, the composition of which does not correspond to the rational norms of consumption of a healthy person.

Poverty is a threat to economic security, as it slows down economic growth. The poor have no motivation to increase productivity, shadow employment, the amount of necessary social support, and employers, in the presence of cheap labor, are not interested in introducing innovations and improving production technology.

The socio-economic impact of the executive power on the management should be influenced. To assess this impact, we use the data of two ratings, namely the rating of the efficiency of the gubernators [9] and the rating of the socio-economic situation of the subjects of the Russian Federation by the results of 2016 [10].

The governors' rating took into account media statistics (qualitative and quantitative indicators of media reports on the activities of the head of a particular region), intelligence services data on the level of tranquility (actions that could lead to a threat to political stability), economic indicators, insider information (about the governor: relations with the administration of the president, the ROC, etc.).

The index of social and economic development of the regions includes 15 indicators, grouped into four groups: the scale of the economy; efficiency of the economy; budgetary sphere; social sphere.

The dependence shows the presence of a weak polynomial dependence $\left(R^{2}=0.164\right)$ between the administrative influence of the executive power (its effectiveness) and the 
socio-economic development of the regions. This confirms the need for the state's influence on social processes in economic life.

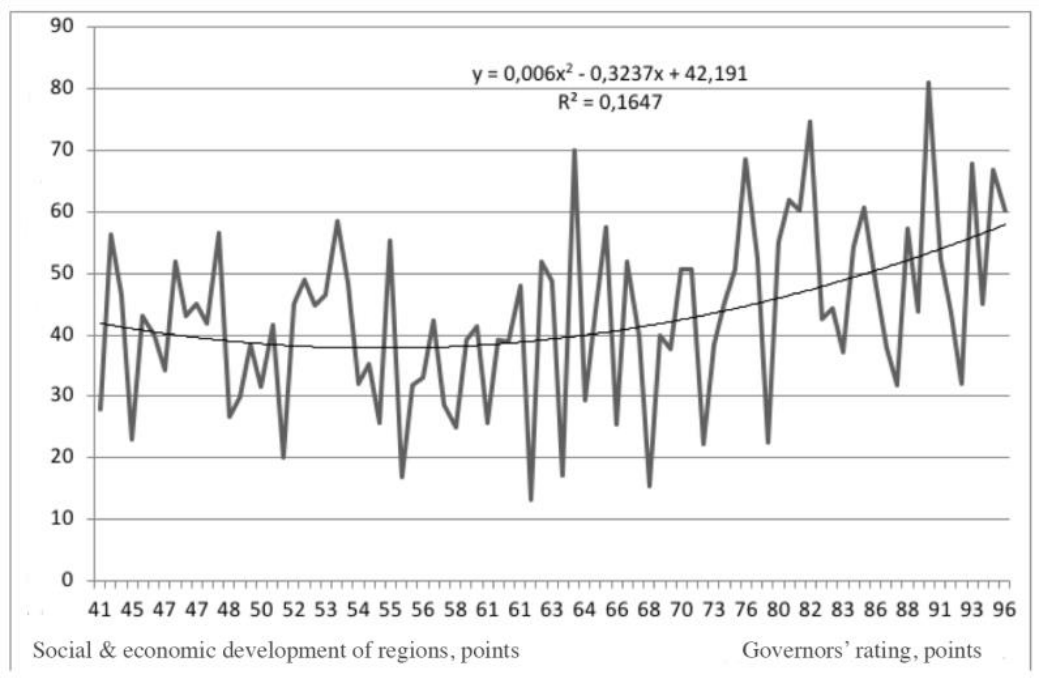

Fig. 4. Dependence of the socio-economic situation of the regions of the Russian Federation from management impact, scores

Because of the further increasing inequality in the distribution of the incomes of the population of Russia, their low level in the main part of the population and its concentration in hands of a small group of people, the aggregate consumer demand is becoming onesided, which does not contribute to the development of production and the real sector of the economy.

The means of overcoming inequality and poverty is the state income policy: regulating the incomes of the population; redistribution of revenues through the state budget.

In the socio-economic development of regions, it is necessary to increase the effectiveness of the executive branch. It is also necessary to improve the estimates of poverty, the subsistence level and the minimum wage. The problem of the working poor should be reflected in the strategic policy documents of the state, determine the target indicators for its resolution.

\section{References}

1. L. N. Dobryshina, Transportnoe delo Rossii, 10 (2011)

2. L. M. Eremeev, Vestnik Kazanskogo Gosudarstvennogo Agrarnogo Universiteta, 4, 7 (2012)

3. TASS, Putin: the work of the Central Bank and the Cabinet helped to achieve the minimum inflation in the history of Russia (Moscow, 2017)

4. V. K. Senchagov, A. N. Solovev, Problemy teorii i praktiki upravlenija, 5 (2015)

5. X. M. Hadzhalova, Nacionalnye interesy: prioritety i bezopasnost, 2 (2010)

6. Novye izvestija, The upper middle class is living well in Russia (Moscow, 2017)

7. Rosstat, Russia and countries of the world (Rosstat, Moscow, 2016)

8. Russia Segodnya, Rich and poor families - regions ranking of 2017 (Moscow, 2017)

9. K. R. Makkonnell, S. L. Brju, Economics: Principles, problems and politics (Respublika, Moscow, 1992) 
10. Profil, Rating of the governors of Russia (Profil, Russia, 2016)

11. RossiaSegodnya, Rating of the governors of Russia (Moscow, 2016) 